\title{
MALAYSIAN L2 LEARNERS' ENGLISH LEARNING MOTIVATION: A STUDY OF GOALS, ATTITUDES AND SELF
}

\author{
K.S.N. Prasangani \\ Centre for Language Studies, Universiti Malaysia Sarawak \\ nilushikap@yahoo.com
}

\begin{abstract}
This paper investigates factors motivating Malaysian students to learn English through Dornyei's (2009) construct of the L2 Motivational Self System. The purpose of the study is to examine the validity of self- concept (Ideal L2 and Ought to L2) in the L2 Motivational Self System and examine effect of learner social goals. Furthermore, the study aims to determine the relationship among L2 attitudes, social goals and motivated learning behaviour. Data were collected through a questionnaire survey conducted among 76 Malaysian undergraduates. The results of the study revealed a strong correlation between social goals and selves as well as social goals and motivated learning behaviour. There was a correlation between the L2 self and motivated learning, suggesting social interference to be an important factor for forming attitude.
\end{abstract}

Keywords: goals, selves, attitudes, L2 Motivation

\section{Introduction}

The research direction of language learning motivation has changed considerably over the past decades due to the spread of globalisation. Gardner's pioneering motivation theories rooted in principles of integrativeness have been subjected to huge criticisms. As posited by van Rooy (2006), the untenable integrativeness has been questioned due to the expansion of new inner circles of concentric model where local L2 varieties are becoming more established in the L2 world, making previous factors redundant or less important. In fact, the concept of integrativeness has been questioned further in terms of whether all learners really want to be a member of imagined global English speaking community to achieve their goals. What is obvious is that learners have now developed their bicultural identity with reference to local culture and global culture (Arnett, 2002) and prefer to view themselves as closer to their local English speaking communities. In reality, globalisation has affected the learner's psychological attachment to the native language community and the need to integrate with the L 2 culture is outdated. 
The controversy about integrativeness has been countered by the L2 Motivational Self-System (LMSS) which was prioritised as the learner's self-concept. In addition, the learners' ideal future image was accounted as a strong predictor of motivation (Dornyei, 2009).

The current research seeks to investigate the relationship of learner goals, selves, attitudes, and motivation by exploiting Dornyei's LMSS as grounded theory.

\section{Literature Review}

\section{Motivation theory}

Over the past decade motivation theory has transformed from integrativeness to LMSS. Gardner's pioneering studies on integrativeness as the key factor to language learning motivation and his socio-educational model is increasingly being seen as less significant. In Gardner's theory, integrativeness was referred to as the learner's desire to learn the language to become close to the L2 community and its culture (Gardner, 2001). However, globalisation has brought about new views over the past decade forcing researchers to heighten the need to re-conceptualise the factors contributing to language learning motivation. Rapid changes in the identity of English language in terms of "world English" and its dominance as the communication mode of globalisation has renewed the interest of going beyond the traditional integrativeness principles (Coetzee-van Rooy, 2006; Lamb, 2004). Nevertheless the questions raised concerning the integrativeness principle were solved through the implementation of Dornyei's LMSS (Dornyei \& Csizer, 2005). In brief, Dornyei's LMMS has three main components. The first one is Ideal L2 self which denotes the L2 specific facet of one's ideal self and which acts as the motivator of language learning. The second is Ought to L2 Self which concerns the attributes one ought to achieve to overcome the possible negative outcomes. Third being the L2 Learning Experience which concerns the situated motives related to the immediate learning environment such as the impact of the teacher, curriculum, and peers (Dornyei, 2010). Presently, recent developments in motivation theories have led to renewed interest in learner self along with the LMSS. A number of researchers worldwide have confirmed the validity of LMSS by focusing on different learner groups (Csizer \& Kormos, 2009; Islam, Lamb, \& Chambers, 2013; Kormos, Kiddle, \& Csizer, 2011; Lamb, 2012; Papi, 2010; Taguchi, Magid, \& Papi, 2009). In fact, the learner self was identified as the predominant factor for language learning motivation. New components were added into the LMSS to identify and define learner self. The Ideal $\mathrm{L} 2$ self and learning experiences were found to be factors for reducing the anxiety and Ought to $L 2$ self as the factor of increasing the anxiety (Papi, 2010). International posture was found to be a causative factor of Ideal L2 self (Csizer \& Kormos, 2009; Kormos et al., 2011). More recently parental encouragement has been added to the LMSS and there has been found a significant correlation with the Ought to L2 self (Csizer \& Kormos, 2009; Kormos et al., 2011). International posture (desire to connect with the international community) was added into the LMSS as an additional goal. As a result, a new interactive model including goals, attitudes and selves was implemented for assessing learner 
motivation over time. Presently, international posture has proven to be a significant factor for increasing the ideal L2 self (Kormos et al., 2011). With learner goals' becoming important predictors of the self-concept, they are also being viewed as the energy of motivation and source of sustaining the effort and achievement (Mercer, Ryan, \& Williams, 2012). However there has been little attention on the whole concept of learner goals including their academic goals and social goals. Recently, most motivation studies have been carried out in urban or metropolitan areas with little attention being paid to South East Asian language learners. This issue has been highlighted in a recent Indonesian study but the study was not able to explore the strong ideal L2 self-due to the relatively young age of the respondents (Lamb, 2012). Similarly, the concept of national identity in Asia appears to have emerged due to the spread of globalisation and a recent study in Pakistan found national interest to be a significant factor for improving Ideal L2 self (Islam et al., 2013). However, far too little attention has been paid to the national identities of the learners.

\section{Goals}

Goals are identified as the cognitive representation of what an individual is trying to achieve in a given situation. As such paying attention to the content of learner goals will enable researchers to understand how multiple goals like social and academic needs can affect learners' academic success (Wentzel, 2000). Often, learner goals vary within and between the cultures according to the cultural context as often indicated by a number of researchers (Lin, Siegler, \& Sullivan, 2010). As such, motivational theorists have divided academic goals or achievement goals into two basic categories. Mastery goals often denote the development of the learner ability and performance goals denote the demonstrating ability or avoiding demonstrating lack of ability (Midgley, Kaplan, \& Middleton, 2001). Mastery goals are identified as related to the learning and thinking process in achievement situations and are linked with the adaptive orientation toward life. This includes encouraging appropriate social behaviour, positive feeling about self and others, and an overall sense of wellbeing. Presently, performance goals have been found to be problematic, because these goals highly consider the achievement as valuable. In many cases when students believe that they lack the competence to perform effectively and they are concerned with failure, performance goals are seen as harmful (Kaplan \& Maehr, 2006). Both performance goals and mastery goals can be identified as individualistic goals, because they neglect the social reasons that motivate to achieve academic success (King \& Watkins, 2011). Given the context that Asian students' academic achievement are closely related to socially oriented goals, there is a need to determine if Asian students' L2 goals may be different. In this matter, parent orientation and teacher orientation have been identified as socially oriented motivations of Filipino university students and personal performance and personal goal choice as individual motivation orientations (Bernardo, 2008). These findings may be applicable to other parts of Asia as well but there is a need to establish this setting for other parts of Asia as well. Presently, there has been little discussion about learner goals and the L2 self in relation to English language learning 
motivation. Kormos et al (2011) looked at a number of factors, did not take into account the learners' social goals, though the study was able to proof the impact of international posture to be a goal to the Ideal L2 in Chile (Kormos et al., 2011) .

This paper is therefore an attempt to illustrate the relationship between learner social goals and selves and, on the other hand, relationship between the social goals, L2 attitude, and motivation in the South East Asia context where national identities, parental guidance and teacher orientation act as a predominant factor in directing learner achievements. To determine the strength of relationships, three research questions were formulated as follows:

1. How social goals affect to LMSS in Malaysian context?

a. What is the relationship between learner social goals and selves?

b. What is the relationship between learner social goals and motivated learning?

2. How LMSS applicable to Malaysian context?

a. What is the relationship between ideal $\mathrm{L} 2$ self and motivated learning?

b. What is the relationship between Ought to L2 self and motivated learning?

3. How $L 2$ attitude affects to English learning?

a. What is the relationship between $\mathrm{L} 2$ attitude and social goals?

b. What is the relationship between $\mathrm{L} 2$ attitude and motivated learning?

\section{Method}

This study involved 76 undergraduates aged between 22 and 25 from a university in Malaysia. Participation was voluntary. The participants were from various faculties in the university and regions of Malaysia. Tables 1, 2, and 3 show the distribution of the subjects by state. Most students came from the states of Kelantan and Sarawak, and they had a limited level of English. In terms of first language, 68 percent of the students indicated Malay as their mother tongue or L1.

Data were gathered through a questionnaire. Questionnaires were filled leisurely at the university hostels. The Malaysian Entrance Test (MUET) band level was taken as the indicator for learners' perceived intellect at the point of study. All participants took the required English courses at the time of the study.

A questionnaire on motivation and goals was developed to gather views of learners. Previously developed motivation questionnaires of Taguchi et. al (2009), Islam et.al (2013), Dowson \& Mclnerney (2004), Dornyei and et. al (1994), and Lamb (2012) were adapted to design the questionnaire. Firstly, the questionnaire was piloted among the 31 undergraduates in a university in Malaysia. The final version of the questionnaire consisted of 36 five-point Likert scale items and took an average of 10 minutes to complete. The scales are as follows. 
Table 1

Distribution of participants by state in Malaysia

\begin{tabular}{lc}
\hline State & $\begin{array}{c}\text { Percentage } \\
(\mathrm{N}=76)\end{array}$ \\
\hline Sarawak & 27 \\
Kelantan & 16 \\
Johor & 9 \\
Pahang & 8 \\
Perak & 8 \\
Sabah & 6 \\
Selangor & 6 \\
Terengganu & 6 \\
Kuala Lumpur & 4 \\
Melaka & 3 \\
Perlis & 3 \\
Penang & 2 \\
Negeri Sembilan & 1 \\
Kedah & 1 \\
\hline Total & 100 \\
\hline
\end{tabular}

Table 2

Distribution of participants by academic discipline

\begin{tabular}{lc}
\hline Academic discipline & $\begin{array}{c}\text { Percentage } \\
(\mathrm{N}=76)\end{array}$ \\
\hline Applied \& creative arts & 38 \\
Social sciences & 20 \\
Cognitive science \& human development & 11 \\
Economics and business & 17 \\
Computer science \& information technology & 8 \\
Resource science \& technology & 4 \\
Engineering & 2 \\
\hline Total & 100 \\
\hline
\end{tabular}

Table 3

Distribution of mother tongues of participants

\begin{tabular}{lc}
\hline Mother tongue & Percentage $(\mathrm{N}=76)$ \\
\hline Malay & 68 \\
Chinese & 16 \\
Iban & 12 \\
Tamil & 4 \\
\hline Total & 100 \\
\hline
\end{tabular}


1. Motivated learning: This scale measures extent of motivated learning of learners

2. Ideal L2 self: The items are designed to measure imagined personality of learners they wish to achieve through learning English

3. Ought to L2 self: The obligations and responsibilities they wish to accomplish to avoid negative future outcomes are measured through this scale

4. Social goals: Socially constructed aspirations of the learners included into this scale

5. L2 attitude: Learners' attitudes towards travel in English speaking countries and meet English speaking people included into this scale

Data were first subjected to SPSS 21.0 for the Pearson Correlation test. Then reliability analysis was run to check Cronbach's Alpha internal consistency reliability coefficients of the items. Correlation analysis used as the basic statistical analysis method to examine correlation between the independent variables and dependent variable.

\section{Results and Discussion}

The various items were tested for their reliability and the scores are presented in Table 4. The scores were in accordance with the Cronbah's Alpha requirement which is above 0.7 (Pallant, 2007) and this makes the test items for the various groupings reliable.

Table 4

Reliability of the variables

\begin{tabular}{lcc}
\hline Variables & No of items & $\mathrm{A}$ \\
\hline Motivated Learning Behavior & 10 & .890 \\
Ideal L2 self & 8 & .935 \\
Ought to L2 self & 4 & .816 \\
Social Goals & 8 & .901 \\
L2 Attitude & 6 & .873 \\
\hline
\end{tabular}

\section{Correlation between Social Goals and Selves}

The mean and standard deviation for Ideal $\mathrm{L} 2$ self and social goals was established to be at $\mathrm{x}=31.8421$ ( $\mathrm{SD}=5.41369)$ and $\mathrm{x}=32.8289$ ( $\mathrm{SD}=5.00237)$ respectively, and the correlation effect was significant as indicated in Table 5 .

Table 5

Correlation between Ideal L2 Self \& Social Goals

\begin{tabular}{lcccc}
\hline $\begin{array}{l}\text { Independent } \\
\text { Variables }\end{array}$ & $\begin{array}{c}\text { Dependent } \\
\text { Variable }\end{array}$ & $\begin{array}{c}\text { Pearson } \\
\text { Correlation }\end{array}$ & $\begin{array}{c}\text { Sig. }(2- \\
\text { tailed) }\end{array}$ & $\mathrm{N}$ \\
\hline Social Goals & Ideal L2 self & $.600^{* *}$ & .000 & 76 \\
\hline
\end{tabular}

$* *$ Correlation is significant at 0.01 confidence level (2-tailed) 
As Table 5 shows, there is a strong correlation between learner social goals and the Ideal L2 self. The findings of the current study added an additional explanation for Kormos et. al (2011) study, which indicated international posture as a causative factor of Ideal L2 self. Furthermore, the findings of the current study highlight the Asian L2 learners' strong attachment of ideal L2 self with the society. This result may be due to the Asian students' dependency on co-participants in the society (parents, friends, siblings, teachers) (Markus et al., 1991). This finding has important implications for developing L2 Motivational Self system of Asian learners.

\section{Correlation between Ought to L2 Self and Social Goals}

The mean value for the Ought to L2 self and social goals was 15.3158 (SD =3.11645) and 32.8289 ( $S D=5.00237)$ respectively. Table 6 indicates a significant relationship between the Ought to L2 self and the social goals.

Table 6

Correlation between Ought to L2 self \& Social Goals

\begin{tabular}{lllll}
\hline $\begin{array}{l}\text { Independent } \\
\text { Variables }\end{array}$ & $\begin{array}{l}\text { Dependent } \\
\text { Variable }\end{array}$ & $\begin{array}{l}\text { Pearson } \\
\text { Correlation }\end{array}$ & Sig. (2 -tailed) & $\mathrm{N}$ \\
\hline Social Goals & Ought to L2 self & $\mathbf{. 5 7 9 * *}$ & $\mathbf{. 0 0 0}$ & $\mathbf{7 6}$ \\
\hline
\end{tabular}

$* *$ Correlation is significant at 0.01 confidence level (2-tailed)

The strongest correlation between social goals and Ought to L2 self is highlighted in Table 6. Interestingly this correlation is related to the Dornyei's LMSS (2005) who found a strong correlation between instrumentality and milieu. This finding further highlights the learners' close bond with the society. They expect to focus their goals to satisfy the needs of the society. In that scenario, parental pressures seem to be a pertinent factor of Asian learner motivation. Moreover, this finding further proves the learners' positive feeling about self, others and sense of wellbeing (Kaplan \& Maehr, 2006), because they do have necessary duties to accomplish by learning English.

\section{Correlation between Motivated learning and social goals}

The mean value and standard deviation for the motivated learning and the social goals was found to be at $x=39.6053(S D=6.13858)$ and $x=32.8289(S D=5.00237)$. respectively Table 7 indicates the significant correlation between motivated learning and social goals.

Table 7

Correlation between Motivated Learning \& Social Goals

\begin{tabular}{lllll}
\hline $\begin{array}{l}\text { Independent } \\
\text { Variables }\end{array}$ & $\begin{array}{l}\text { Dependent } \\
\text { Variable }\end{array}$ & $\begin{array}{l}\text { Pearson } \\
\text { Correlation }\end{array}$ & $\begin{array}{l}\text { Sig. } \\
\text { tailed })\end{array}$ & \\
\hline Social Goals & $\begin{array}{l}\text { Motivated } \\
\text { Learning }\end{array}$ & $.623^{* *}$ & .000 & 76 \\
\hline
\end{tabular}

** Correlation is significant at 0.01 confidence level (2-tailed) 
In accordance with Table 7 learners' social goals have a significant correlation with the motivated learning. This result provides further support for the hypothesis that goals have a dominant role in learner motivation. In this study, social goals have a significantly strong relationship to motivated learning. This finding, while preliminary, suggests the increasing demand for English in the Asian social context due to the spread of globalisation. This also accords with Ushioda (2013), who suggested the expansion of English language identity and the loss of its boundaries of culture, values and standards due to the globalisation. Due to the huge social demand for English in the Asian context, learners are motivated to learn English to achieve their social goals of acquiring social respect, to serve and represent the country.

\section{Correlation between Selves and Motivated Learning}

The mean and standard deviation for motivated learning and ideal L2 self and ought to $L 2$ self were found to be at $x=39.6053$ ( $S D=6.13858) ; x=31.8421$ ( $S D=5.41369)$ and $\mathrm{x}=15.3158(\mathrm{SD}=3.11645)$ respectively. Table 12 indicates the correlations of motivated learning, Ideal $L 2$ self and Ought to $L 2$ self.

Table 8

Correlation between Selves \& Motivated Learning

\begin{tabular}{llccc}
\hline $\begin{array}{l}\text { Independent } \\
\text { Variables }\end{array}$ & $\begin{array}{l}\text { Dependent } \\
\text { Variable }\end{array}$ & $\begin{array}{c}\text { Pearson } \\
\text { Correlation }\end{array}$ & $\begin{array}{c}\text { Sig. }(2- \\
\text { tailed) }\end{array}$ & $\mathrm{N}$ \\
\hline Ideal L2 Self & $\begin{array}{l}\text { Motivated } \\
\text { Learning }\end{array}$ & $.713^{* *}$ & .000 & 76 \\
$\begin{array}{l}\text { Ought to L2 } \\
\text { Self }\end{array}$ & $\begin{array}{l}\text { Motivated } \\
\text { Learning }\end{array}$ & $.470^{* *}$ & .000 & 76 \\
\hline
\end{tabular}

${ }^{* *}$ Correlation is significant at 0.01 confidence level (2-tailed)

With reference to the Table 8, Ideal L2 self has the strongest correlation with motivated learning. The reason for this is that university students as adults are highly motivated in terms of learning English because English is the key for many of them to achieve their academic success and future professional success. This finding further confirms earlier findings in motivation studies (Csizer \& Kormos, 2009; Islam et. al, 2013; Kormos et. al, 2011). However, this result differs from some published studies (Papi, 2010; Taguchi et. al, 2009), which found the highest correlation of learning experiences and attitudes with the criterion measure. In contrast to earlier findings of Kormos et. al (2011); Papi (2010); Taguchi et. al (2009) and Csizer and Kormos (2009), this study found a strong correlation between ought to L2 self and motivated learning. This result is due to the strength of responsibilities and obligations of Asian learners in the L2 context. Nevertheless, this needs to be interpreted with caution because the findings are based on a specific $L 2$ context where students come from different academic disciplines. 


\section{Correlation between $L 2$ attitudes and social goals}

The mean and standard deviation for social goals and $\mathrm{L} 2$ attitude was found to be at $\mathrm{x}=32.8289(\mathrm{SD}=5.00237)$ and $\mathrm{x}=23.9342(\mathrm{SD}=3.70346)$ respectively. As indicated in Table 9, it was evident that $L 2$ attitude is a stronger pull factor to social goals. There is clear evidence that the L2 learners' strong desire to be connected with the L2 community is important to accomplish their social goals.

Table 9

Correlation between L2 Attitude and Social Goals

\begin{tabular}{llccc}
\hline $\begin{array}{l}\text { Independent } \\
\text { Variables }\end{array}$ & $\begin{array}{l}\text { Dependent } \\
\text { Variable }\end{array}$ & $\begin{array}{c}\text { Pearson } \\
\text { Correlation }\end{array}$ & $\begin{array}{c}\text { Sig. }(2- \\
\text { tailed) }\end{array}$ & $\mathrm{N}$ \\
\hline L2 Attitude & Social Goals & $.444^{* *}$ & .000 & 76 \\
\hline
\end{tabular}

${ }^{* *}$ Correlation is significant at 0.01 confidence level (2-tailed)

The current study is parallel with the findings of Kormos et. al (2011) because they found a significant contribution of parental encouragement to the $L 2$ learning attitude. Moreover, according to the findings, it can be predicted that Malaysian learners L2 attitude is influenced by their social goals. This further denotes the significance of social attachment in English learning context.

\section{Correlation between $\mathrm{L} 2$ attitudes and motivated learning}

The mean and standard deviation of $\mathrm{L} 2$ attitudes and motivated learning was found to be at $x=23.9342(S D=3.70346)$ and $x=39.6053(S D=6.13858)$ respectively. Table 10 emphasises the correlation between $\mathrm{L} 2$ attitudes and motivated learning.

Table 10

Correlation between L2 Attitudes and Motivated Learning

\begin{tabular}{llccc}
\hline $\begin{array}{l}\text { Independent } \\
\text { Variables }\end{array}$ & $\begin{array}{l}\text { Dependent } \\
\text { Variable }\end{array}$ & $\begin{array}{c}\text { Pearson } \\
\text { Correlation }\end{array}$ & $\begin{array}{c}\text { Sig. (2- } \\
\text { tailed) }\end{array}$ & $\mathrm{N}$ \\
\hline L2 Attitude & $\begin{array}{l}\text { Motivated } \\
\text { Learning }\end{array}$ & $.686^{* *}$ & .000 & 76 \\
\hline
\end{tabular}

**Correlation is significant at 0.01 confidence level (2-tailed)

It can be seen from the Table 10 that $\mathrm{L} 2$ attitude and motivated learning are strongly correlated. This signifies the significance of L2 attitudes related to the communication and travel in English speaking countries of learners in motivated learning. Moreover, findings of the current study are consistent with the study of Yashima (2004) because like Japanese Foreign Language Malaysian learners are motivated to learn English for travelling and communication purposes. It can be noted that learners are motivated to learn English due to social requirements and the international purposes especially in Asian countries. 


\section{Conclusion}

This paper has given an account of goals, selves and English learning motivation of Malaysian students. This investigation was aimed at examining the relationship between social goals and selves, social goals and motivated learning, selves and motivated learning, social goals and L2 attitude, and L2 attitude and motivated learning. The applicability of Ideal L2 self and Ought to L2 self in Asian context is further validated by the findings. It has also shown a strong correlation between Ideal L2 self and motivated learning. The most obvious finding to emerge from this study is the significant correlation of social goals to the learner self and motivated learning. Generally, this study has found that learner social goal as an important indicator of learner self-concept and motivation. Taken together, these results suggest that L2 learners in Asia have a strong link with the society, and their goals, selves, attitudes and motivation are derived from the values and norms of the society. The empirical findings in this study provide new understanding of self and motivation of Asian L2 learners.

This research has opened up a number of questions that are in need of further investigation. Additional work needs to be done to establish the social goals in the L2 motivational self -system. Further research might be required to better explore the learner self and goals in different Asian social settings and specific disciplines. More information on social goals would help us to establish a clearer picture of the social goals of $L 2$ learner's motivational self-system.

\section{References}

Arnett, J. J. (2002). The psychology of globalization. American Psychologist, 57(10), 774-783. doi:10.1037//0003-066X.57.10.774

Bernardo, A. B. I. (2008). Individual and social dimensions of Filipino students' achievement goals. International Journal of Psychology: Journal international de psychologie, 43(5), 886-891. doi:10.1080/00207590701837834

Coetzee-van Rooy, S. (2006). Integrativeness: untenable for world Englishes learners? World Englishes, 25(3-4), 437-450. doi:10.1111/j.1467971X.2006.00479.x

Csizer, K., \& Kormos, J. (2009). Learning experiences, selves and motivated learning behaviour: A comparative analysis of structural models for Hungarian secondary and university learners of English. In Motivation, language identity and the L2 Self (pp. 98-119).

Csizér, K., \& Dörnyei, Z. (2005). The internal structure of language learning motivation and its relationship with language choice and learning effort. The Modern Language Journal, 89(1), 19-36.

Dornyei, Z. (2005). The psychology of the language learner: Individual differences in second language acquisition. US: Lawrence Erlbaum Associates.

Dornyei, Z. (2009). The L2 motivational self-system. In Z. Dornyei \& E. Ushioda (Eds.). Motivation, language identity and the L2 self (pp. 9-42). Clevedon, UK: Multilingual Matters. 
Dornyei, Z. (2010). Researching motivation: From integrativeness to the ideal L2 self. In S. Hunston \& D. Oakey (Eds.) Introducing applied linguistics: Concepts and skills (pp. 74-83). London: Routledge.

Dornyei, Z., \& Csizer, K. (2005). The internal structure of language learning motivation and its relationship with language choice and learning effort. The Modern Language Journal, 89(i), 19-36.

Dowson, M., \& Mclnerney, D. M. (2004). The development and validation of the goal orientation and Learning Strategies Survey (Goals-S). Educational and Psychological Measurement, 64(2), 290-310. doi:10.1177/0013164403251335

Gardner, R. C. (2001). Language learning motivation: The student, the teacher, and the researcher. Texas Papers in Foreign Language Education, 6(1), 1-18. doi:10.1177/0261927X99018004004

Islam, M., Lamb, M., \& Chambers, G. (2013). The L2 Motivational Self System and national interest: A Pakistani perspective. System, 41(2), 231-244. doi:10.1016/j.system.2013.01.025

Kaplan, A., \& Maehr, M. L. (2006). The contributions and prospects of Goal Orientation Theory. Educational Psychology Review, 19(2), 141-184. doi:10.1007/s10648-006-9012-5

King, R. B., \& Watkins, D. a. (2011). "Socializing" Achievement Goal Theory: The need for social goals. Psychological Studies, 57(1), 112-116. doi:10.1007/s12646011-0140-8

Kormos, J., Kiddle, T., \& Csizér, K. (2011). Goals, attitudes and self-related beliefs in second language learning motivation: An interactive model of language learning motivation Judit Kormos, Thom Kiddle and Kata Csizér. Applied Linguistics, 32(5), 495-516.

Lamb, M. (2004). Integrative motivation in a globalizing world. System, 32(1), 3-19. doi:10.1016/j.system.2003.04.002

Lamb, M. (2012). A self system perspective on young adolescents' motivation to Learn English in urban and rural settings. Language Learning, 62(4), 997-1023. doi:10.1111/j.1467-9922.2012.00719.x

Lin, X., Siegler, R. S., \& Sullivan, F. R. (2010). Students' goals influence their learning. In D. D. Preiss \& R. J. Sternberg (Eds.), Innovations in educational psychology Perspectives on learning teaching and human development (pp. 79-105). Springer.

Markus, H. R., Cross, S., Fiske, A., Gilligan, C., Givon, T., Kanagawa, C., ... Miller, J. (1991). Culture and the self: Implications for cognition, emotion, and motivation, 98(2), 224-253.

Mercer, S., Ryan, S., \& Williams, M. (2012). Self-concept: Situating the Self. In S. Mercer, S. Ryan, \& M. Williams (Eds.), Psychology for Language Learning (pp. 10-26). Basingstoke: Palgrave Macmillan. doi:10.1057/9781137032829

Midgley, C., Kaplan, A., \& Middleton, M. (2001). Performance-approach goals: Good for what, for whom, under what circumstances, and at what cost? Journal of Educational Psychology, 93(1), 77-86. doi:10.1037//0022-0663.93.1.77

Papi, M. (2010). The L2 motivational self system, L2 anxiety, and motivated behavior: A structural equation modeling approach. System, 38(3), 467-479. doi:10.1016/j.system.2010.06.011 
Taguchi, T., Magid, M., \& Papi, M. (2009). The L2 motivational self system among Japanese, Chinese and Iranian Learners of English: A comparative study, 6697.

Ushioda, E. (2013). Motivation and ELT: Global Issues and local concerns. In E. Ushioda (Ed.), International perspectives on motivation: Language learning and professional challenges (pp. 1-17). Basingstoke: Palgrave Macmillan.

Wentzel, K. (2000). What is it that I'm trying to achieve? Classroom goals from a content perspective. Contemporary educational psychology, 25(1), 105-115. doi:10.1006/ceps.1999.1021 